\title{
STUDIES ON THE MECHANISM OF PROTEINURIA
}

\author{
By E. HENRY KEUTMANN and SAMUEL H. BASSETT \\ (From the Department of Medicine, University of Rochester School of Medicine and Dentistry \\ and the Medical Clinic of the Strong Memorial and Rochester Municipal \\ Hospitals, Rochester, N. Y.)
}

(Received for publication May 4, 1937)

In the chronic active stage of hemorrhagic Bright's disease there are often comparatively long intervals when the amount of functioning kidney tissue decreases very slowly and when there is no marked variation in glomerular permeability. With the patient on a standard regime the urea clearance remains constant, proteinuria fairly so, and blood samples taken under basal conditions with precautions against stasis and effects of posture contain nearly constant percentages of plasma proteins (18). Under such circumstances, some of the factors governing proteinuria may be studied.

The amount of protein in the urine, as well as its level in the circulating plasma, seems to depend largely upon the nature and severity of injury to the glomerular capillaries (14). Proteinuria may also be influenced in a moderate degree by the level of protein in the diet $(4,11,18)$. In addition to these factors there are apparently others which induce temporary fluctuations in proteinuria. The observations reported here were made in an effort to clarify the problem further.

Our results support the concept that the quantity of protein lost in the urine is related to the amount of glomerular filtrate formed and to the rate of production of serum proteins.

\section{METHODS}

Subjects. The investigations were conducted on four patients with chronic active hemorrhagic Bright's disease. Three of these had served as subjects for previous studies and their medical histories have been summarized elsewhere $(18,19)$.

The fourth patient (J. H.) was a married woman of 25 years of age. She had scarlet fever at the age of fourteen. Protein was first discovered in the urine during pregnancy at the age of eighteen. During her twentyfirst year she contracted and received treatment for gonorrhea. Clinical cure of the venereal infection resulted. During her twenty-second and twenty-third years she was ill on several occasions with acute sinusitis. Two months prior to admission her face became swollen, and she was told by a physician that she had Bright's disease.
Her treatment at this time consisted of frequent cathartic doses of epsom salts and a low protein diet. A week before admission edema developed in the lower extremities and gradually extended upward to involve the abdominal wall. Physical examination revealed pallor of the skin and mucous membranes; soft pitting edema of the face, trunk and lower extremities. The systolic blood pressure was $160 \mathrm{~mm}$. of mercury; the diastolic $100 \mathrm{~mm}$. The heart was normal. A careful search for foci of infection was made, but except for scarred tonsils none were found. The blood, at the time of admission contained $3,200,000$ erythrocytes and 8,100 leukocytes per cubic millimeter; hemoglobin 9.4 grams; nonprotein nitrogen $32 \mathrm{mgm}$., and serum proteins 3.3 grams per $100 \mathrm{ml}$. The albumin: globulin ratio of the serum proteins was 1.3. The concentration of chlorides in the serum was 112 m.eq. per liter; $\mathrm{CO}_{2}$ combining power of the plasma was 59 volumes per cent. The urine contained much protein, many casts, red cells and epithelial cells. It was sterile on culture. An Addis sediment count revealed the presence of 13 million erythrocytes, 4 million epithelial and white blood cells, and 66 thousand casts in a twelve hour specimen. Urea clearance was approximately 40 per cent of the normal average.

The patient was given a diet liberal in calories and proteins. She lost her edema and in three weeks the erythrocytes of the blood had increased to $4,000,000$ per cubic millimeter, the hemoglobin to 12.5 grams and the serum proteins to 4 grams per $100 \mathrm{ml}$. There was no further change in these values throughout the balance of her stay in the hospital. Subsequent examinations of the urine showed no marked change from those noted at the time of admission.

None of the patients on whom this report is based had clinical edema while they were subjects of investigation.

Diets. The diets were prepared, sampled and analyzed in a manner previously described (18). During the experiments recorded in Tables I, III and IV the patients were allowed three different menus, which varied slightly but had the same caloric and protein content and were given on consecutive days. The patients thus ate the same food every third day. During the experiments recorded in Tables II, V and VI the patients ate exactly the same food each day. No salt was added to the diets during their preparation, and fluid intake was kept constant in each experiment.

Protein supplements were given in powdered form. Liver protein was prepared as previously described (18). Egg white was boiled, then minced, dehydrated with alcohol, dried in a current of warm air and reduced to 
powder in a ball mill. The kidney protein was prepared from fresh raw beef kidneys, which were washed in running water, then minced, dehydrated, dried and powdered as in the case of egg protein.

Analytical methods. All nitrogen determinations were done in triplicate. The nitrogen content of the diets, the stools and the daily urine was determined by macroKjeldahl. The protein in the urine of Case P. V. in Table I was determined by the method of Kingsbury, Clark, Williams and Post (16). The protein standards used, ranging from 5 to $100 \mathrm{mgm}$. per $100 \mathrm{ml}$., were checked frequently with solutions of known protein content. In all other experiments the protein of the urine was determined by the micro-Kjeldahl method described by Peters and Van Slyke (26). Serum proteins were determined by the method of Howe (26). Blood for these determinations was drawn without stasis in the morning about fourteen hours after the previous meal and while the patients were still recumbent. Plasma volumes were determined by the dye method of Keith, Rowntree and Geraghty (17) as modified by Hooper, Smith, Belt and Whipple (15). The patients were weighed at the same time each morning after emptying the bladder and prior to the ingestion of food. The stools were separated by means of carmine given at the beginning of each metabolic period. The urea clearance tests were done according to the method of Möller, McIntosh and Van Slyke (24). With the exception of those in Table $\mathrm{V}$, the tests were done in duplicate under basal conditions in the morning. A uniform amount of water was given during each series of tests. The clearances in Table V were calculated from the twelve hour urea excretion according to the method of Landis and coworkers (21).

\section{The effect of the protein content of the diet on proteinuria and urea clearance}

Variations in proteinuria and urea clearance with the level of protein in the diet are recorded in Table I. In each case there were simultaneous changes in proteinuria and urea clearance. There was no constant relationship between the proteinuria and the volume of the urine.

The clearances of urea, creatinine, xylose and sucrose have all been found to vary with the level of the protein in the diet, and there is good evidence for the belief that this results from changes in the rates of glomerular filtration (32). Van Slyke, Rhoads, Hiller and Alving (33) found that increase or decrease in urea clearance was accompanied by proportional changes in renal blood flow. It, therefore, seems justifiable to interpret concommitant increase or decrease in proteinuria and urea clearance as the result of changes in renal blood flow and glomerular filtra-
TABLE I

Changes in proteinuria and urea clearance associated with changes in level of protein in the diet

\begin{tabular}{|c|c|c|c|c|c|c|c|c|}
\hline \multirow[b]{2}{*}{ Case } & \multirow[b]{2}{*}{ Day } & \multicolumn{2}{|c|}{ Diet } & \multirow[b]{2}{*}{$\left|\begin{array}{c}\text { Serum } \\
\text { pro- } \\
\text { teins }\end{array}\right|$} & \multicolumn{3}{|c|}{ Urine } & \multirow{2}{*}{$\begin{array}{l}\text { Stand- } \\
\text { ard } \\
\text { urea } \\
\text { clear- } \\
\text { ancet }\end{array}$} \\
\hline & & $\begin{array}{c}\text { Cal- } \\
\text { ories }\end{array}$ & $\begin{array}{l}\text { Pro- } \\
\text { tein }\end{array}$ & & $\begin{array}{l}\text { Vol- } \\
\text { ume }\end{array}$ & $\begin{array}{c}\text { Non- } \\
\text { pro- } \\
\text { tein } \\
\text { nitro- } \\
\text { gen }\end{array}$ & $\begin{array}{l}\text { Pro- } \\
\text { tein }\end{array}$ & \\
\hline & & $\begin{array}{c}\text { per } \\
\text { diem }\end{array}$ & $\begin{array}{c}\text { grams } \\
\text { per } \\
\text { diem }\end{array}$ & $\begin{array}{l}\text { per } \\
\text { cent }\end{array}$ & $\begin{array}{c}\text { ml. } \\
\text { per } \\
\text { diem }\end{array}$ & $\begin{array}{c}\text { grams } \\
\text { per } \\
\text { diem }\end{array}$ & $\begin{array}{c}\text { grams } \\
\text { per } \\
\text { diem }\end{array}$ & $\underset{\text { per }}{\text { minute }}$ \\
\hline $\begin{array}{c}\text { P. V. } \\
\text { March to } \\
\text { May } \\
1931\end{array}$ & $\begin{array}{c}1-6 \\
7-12 \\
13-18 \\
19-24 \\
25-30 \\
31-36 \\
37-42 \\
43-48 \\
49-54 \\
55-60\end{array}$ & $\begin{array}{l}3400 \\
3400 \\
3400 \\
3400 \\
3400 \\
3400 \\
3400 \\
3400 \\
3400 \\
3400\end{array}$ & $\begin{array}{c}75 \\
75 \\
150 \\
150 \\
150^{*} \\
150^{*} \\
150 \\
40 \\
150 \\
150 \\
\end{array}$ & $\begin{array}{l}7.0 \\
7.0 \\
7.3 \\
7.0\end{array}$ & \begin{tabular}{|r|}
1174 \\
1312 \\
1450 \\
1785 \\
1985 \\
1694 \\
1809 \\
1807 \\
1397 \\
964 \\
\end{tabular} & \begin{tabular}{|c}
7.87 \\
8.30 \\
15.30 \\
17.60 \\
17.69 \\
18.58 \\
17.50 \\
6.55 \\
15.9 \\
17.4 \\
\end{tabular} & $\begin{array}{l}0.070 \\
0.090 \\
0.150 \\
0.120 \\
0.340 \\
0.410 \\
0.410 \\
0.150 \\
0.170 \\
0.270\end{array}$ & $\begin{array}{l}23 \\
26 \\
39 \\
42 \\
45 \\
47 \\
26 \\
45 \\
47\end{array}$ \\
\hline$\underset{\substack{\text { L. R. } \\
\text { Januer to } \\
1933-34}}{\text { Jary }}$ & $\begin{array}{c}1-9 \\
10-24 \\
25-36 \\
37-81 \\
102-114\end{array}$ & $\begin{array}{l}3000 \\
3000 \\
3000 \\
3000 \\
3000\end{array}$ & $\begin{array}{r}70 \\
70 \\
180 \\
180 \\
70\end{array}$ & \begin{tabular}{l|}
4.1 \\
4.1 \\
4.0 \\
4.0
\end{tabular} & $\begin{array}{l}2420 \\
2235 \\
2260 \\
2220 \\
1920\end{array}$ & $\begin{array}{r}8.2 \\
7.5 \\
18.6 \\
22.3 \\
9.0\end{array}$ & $\begin{array}{r}9.7 \\
11.6 \\
15.0 \\
13.0 \\
11.2\end{array}$ & $\begin{array}{l}25 \\
20 \\
35 \\
32 \\
22\end{array}$ \\
\hline$\underset{1934}{\text { R. P. P. }}$ & $\begin{array}{r}1-10 \\
11-13 \\
14-22 \\
23-31\end{array}$ & $\begin{array}{l}3200 \\
3200 \\
3400 \\
3600\end{array}$ & $\begin{array}{r}60 \\
60 \\
110 \\
160\end{array}$ & \begin{tabular}{l|}
2.95 \\
2.9 \\
3.0 \\
3.0
\end{tabular} & $\left|\begin{array}{l}1230 \\
1220 \\
1560\end{array}\right|$ & $\begin{array}{r}5.2 \\
8.4 \\
13.0\end{array}$ & $\begin{array}{l}13.5 \\
19.0 \\
23.0\end{array}$ & $\begin{array}{l}21 \\
33 \\
40\end{array}$ \\
\hline
\end{tabular}

* (Case P. V.) From the 25th through the 36th day, 60 grams of protein daily were furnished by liver, in substitution for beef and fish muscle given the balance of the time on the same level of protein.

t Each urea clearance value represents the mean of two or more determinations.

tion. An additional factor must be taken into consideration in Case P. V. From the twentyfifth to the thirty-sixth days inclusive 60 grams of liver protein replaced an equal amount of beef, veal and fish protein in his diet. The substitution of liver protein led to a further rise in the amount of protein in the urine without a corresponding increase in urea clearance. Data from several sources suggest that this is due to the superiority of liver as a source of protein food from which the body can fabricate plasma protein $(18,29)$.

Table II shows the extent of variation in the proteinuria of Case L. R. during two days at different levels of protein intake. In each case he had received the same diet and supplement for five previous days. The patient was kept recumbent in bed during these two days to avoid postural effects. Additional experiments of this nature yielded similar results.

Proteinuria was greater while the patient was taking the higher protein diet. At both levels of intake proteinuria increased during the day. $\mathrm{Ob}$ viously, these variations may have been due to the 
TABLE II

Variation in proteinuria during 24 hour periods in Case $L . R$.

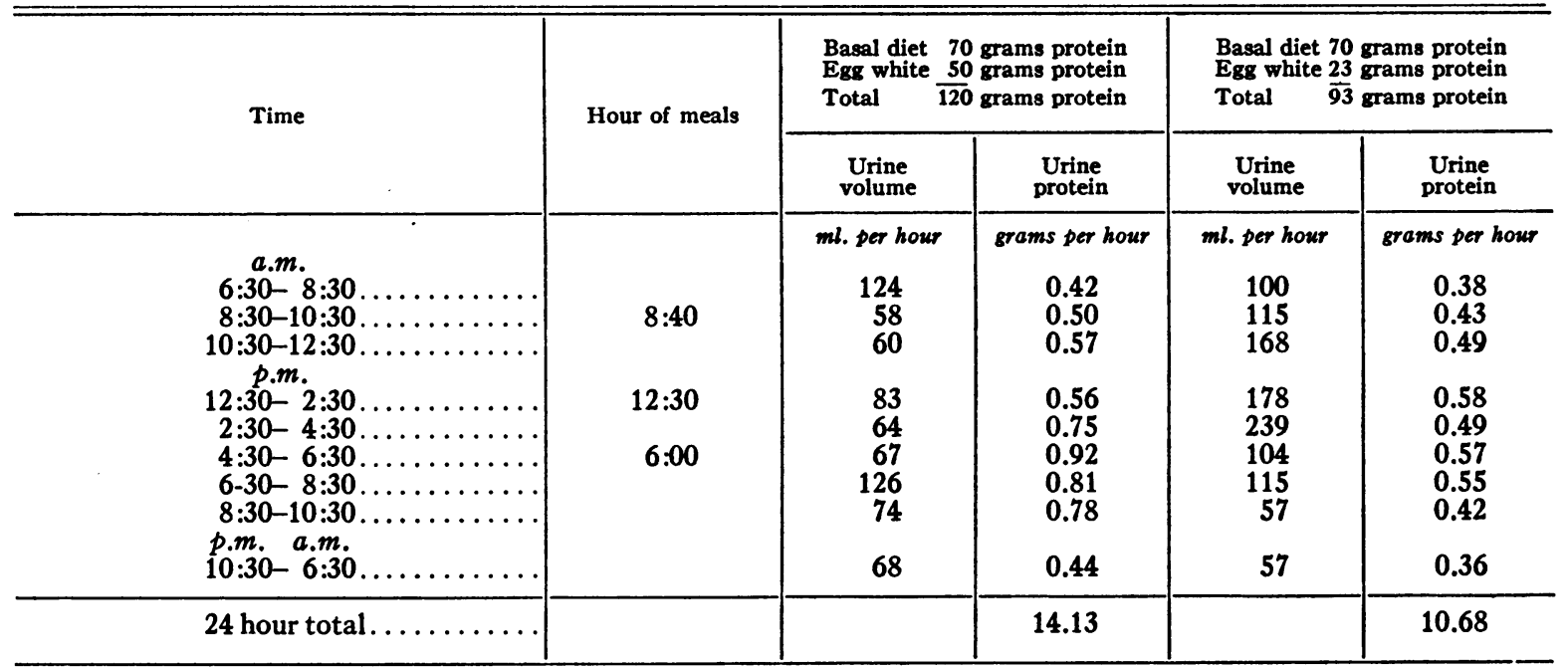

influence of the protein eaten at meal times upon the rate of the glomerular filtration or to an increased rate of manufacture of plasma protein after meals or to a combination of these. Similar diurnal variations in the urea clearance have been found by MacKay (23), and postprandial elevations of urea and xylose clearances have been demonstrated $(27,32)$.

\section{The effect of diuretics}

Theobromine. It is generally conceded that the xanthine diuretics increase the rate of glomerular filtration. Addis and Drury (1) and Polland (28) found that the urea excretory ratio (urea clearance) was increased by the xanthine diuretics. Schmitz has reviewed the extensive literature on the subject and added further evidence for the validity of the concept (31). Page (25) found the variation in urea clearance produced by a single dose of one of the xanthine diuretics not greater than the usual variable conditions existing in patients. This does not, however, invalidate the results obtained by previous investigators.

Data obtained when Cases R. P. and J. H. were given theobromine are recorded in Table III. The total daily dose of the diuretic indicated in the table was given in four portions at intervals of six hours.

Proteinuria and urea clearances were definitely increased above the basal level when theobromine was given. This effect continued for a day or two after the medication was stopped. Then both proteinuria and clearance decreased to about the previous level. Proteinuria during control periods after theobromine administration was slightly less than in preceding controls, probably because of additional depletion of body protein

TABLE III

Effect of theobromine on proteinuria and urea clearance.

\begin{tabular}{|c|c|c|c|c|c|c|c|c|}
\hline \multirow{2}{*}{ Case } & \multirow{2}{*}{ Day } & \multirow{2}{*}{ Diet } & \multirow{2}{*}{$\begin{array}{l}\text { Theo- } \\
\text { bro- } \\
\text { mine } \\
\text { so- } \\
\text { dium } \\
\text { salicy- } \\
\text { late }\end{array}$} & \multicolumn{3}{|c|}{ Urine } & \multirow{2}{*}{$\begin{array}{l}\text { Stand- } \\
\text { ard } \\
\text { urea } \\
\text { clear- } \\
\text { ance }\end{array}$} & \multirow{2}{*}{$\begin{array}{c}\text { Serum } \\
\text { pro- } \\
\text { teins }\end{array}$} \\
\hline & & & & $\begin{array}{l}\text { Vot- } \\
\text { ume }\end{array}$ & $\begin{array}{c}\text { Non- } \\
\text { protein } \\
\text { nitro- } \\
\text { gen }\end{array}$ & $\begin{array}{l}\text { Pro- } \\
\text { tein }\end{array}$ & & \\
\hline & & per diem & $\begin{array}{l}\text { grams } \\
\text { per } \\
\text { diem }\end{array}$ & $\begin{array}{l}\text { ml. } \\
\text { per } \\
\text { diem }\end{array}$ & $\begin{array}{c}\text { orams } \\
\text { per } \\
\text { diem }\end{array}$ & $\begin{array}{l}\text { grams } \\
\text { per } \\
\text { diem }\end{array}$ & $\begin{array}{c}\text { ml. } \\
\text { per } \\
\text { diem }\end{array}$ & per cent \\
\hline R. P.* & $\begin{array}{c}1-13 \\
14 \\
15 \\
16 \\
17-20\end{array}$ & $\begin{array}{c}\text { Caloriea } 3200 \\
\text { Protein 60 } \\
\text { grams }\end{array}$ & $\begin{array}{l}0 \\
5 \\
5 \\
0 \\
0\end{array}$ & $\begin{array}{r}1000 \\
1490 \\
900 \\
1200 \\
1330\end{array}$ & $\begin{array}{l}4.5 \\
5.9 \\
5.4 \\
6.2 \\
5.3\end{array}$ & $\begin{array}{l}14.7 \\
19.6 \\
17.1 \\
18.9 \\
14.0\end{array}$ & $\begin{array}{l}20 \pm 3 \\
35 \pm 2 \\
23 \pm 2\end{array}$ & $\begin{array}{l}3.0 \\
3.1\end{array}$ \\
\hline J. H. $\dagger$ & $\begin{array}{c}1-17 \\
18 \\
19 \\
20 \\
21 \\
22 \\
23-24 \\
25-28 \\
29-31\end{array}$ & $\begin{array}{c}\text { Calories 2500 } \\
\text { Protein 60 } \\
\text { grams }\end{array}$ & $\begin{array}{l}0 \\
0 \\
4 \\
4 \\
4 \\
0 \\
0 \\
0 \\
0\end{array}$ & $\begin{array}{l}2200 \\
1820 \\
2510 \\
2120 \\
1930 \\
2380 \\
1740 \\
\text { Lost } \\
1620\end{array}$ & $\begin{array}{l}7.3 \\
7.1 \\
9.1 \\
7.2 \\
7.0 \\
8.2 \\
6.9 \\
6.7\end{array}$ & $\begin{array}{l}4.7 \\
4.9 \\
6.3 \\
6.5 \\
6.3 \\
6.8 \\
5.7 \\
4.4\end{array}$ & $\begin{array}{l}23 \pm 1 \\
35 \pm 4 \\
36 \pm 3 \\
\\
22 \pm 2\end{array}$ & 4.0 \\
\hline
\end{tabular}

* R. P. From first to 13 th day volume of urine varied between 640 and $1440 \mathrm{ml}$. per day. From first to 13th day protein in urine varied between 14 and 15.1 grams per day. From 17th to 20th day volume of urine varied between 990 and $1680 \mathrm{ml}$. per day. From 17 th to 20 th day protein in urine varied between 13.5 and 14.6 grams per day.

$\dagger \mathrm{J}$. H. From first to 17 th day volume of urine varied between 1760 and $2620 \mathrm{ml}$. per day. From first to 17 th day protein in urine varied between 4.2 and 5 grams per day. 
during the experiment. The results suggest that theobromine caused increase in glomerular filtration.

Berglund and Sundh (5) determined the creatinine clearance and proteinuria before and after administration of euphyllin or caffeine. In most instances the results agreed with our findings. Since Berglund's observations were conducted only during an interval of three hours, the time of maximal effect of the drug may not have been included in all experiments.

Urea has been used as a diuretic for many years, and the mode of its action has been the subject of much investigation and controversy. Gottlieb and Magnus (12) and Fletcher, Henderson and Loewi (10) found evidence of increased renal blood flow after its administration. Henderson and Loewi (13) also obtained evidence of dilution of the blood. Lamy and Mayer (20) found that diuresis occurred without evidence of either of these phenomena. Cushny (8) came to the conclusion that the increase in the amount of urea in the tubules prevented reabsorption of water and that at times this effect was reinforced by increased renal blood flow and increased glomerular filtration resulting from dilution of the blood. These conclusions have been supported by the results different investigators have obtained while working with the urea clearance test. Addis and Watanabe (3) found that the administration of urea often increased the urea clearance above that obtained at normal blood urea levels. Van Slyke, Rhoads, Hiller and Alving (33) studying dogs with explanted kidneys found that the urea clearance was sometimes increased by the administration of urea, more often not. However, the changes in clearance were always found to parallel changes in the renal blood flow. There are several reports in the literature $(4,7)$ showing that administration of urea results in increased proteinuria, but the mechanism of its action was not ascertained. It seems likely that certain factors not yet understood, perhaps the amount of water and electrolytes available for mobilization determine dilution of the blood and expansion of its volume and thus lead to increased glomerular filtration.

Urea was administered to Cases R. P. and J. H. for several successive days while they were on a
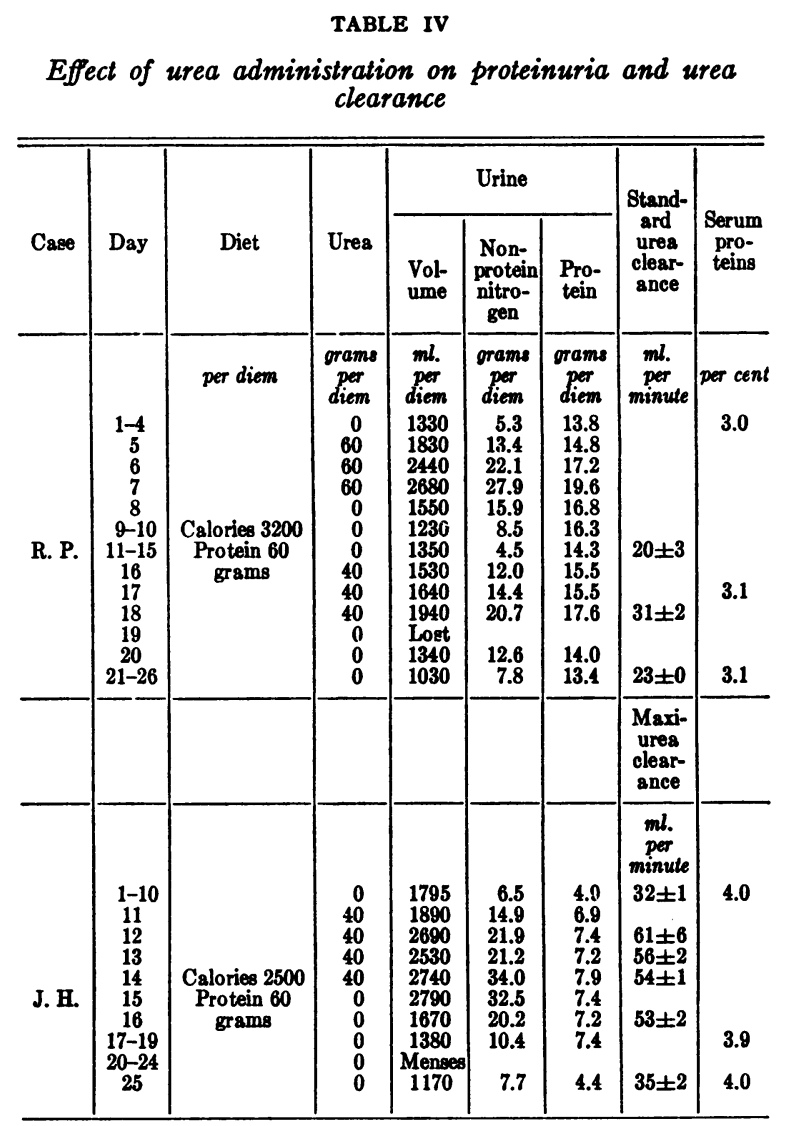

constant dietary and fluid intake. It was necessary to give $100 \mathrm{ml}$. of extra water with each 10 grams of urea. The data are recorded in Table IV. In each instance the urine volume rose above the control level when the larger amounts of urea were excreted. At times the increase in urine was greater than the extra water administered; therefore, fluid must have been withdrawn from the body. The smaller urine volumes during after periods are indications of readjustment.

Proteinuria and urea clearance increased. Both of these effects we believe to have been manifestations of increased glomerular filtration. The increase in proteinuria in Case $\mathrm{J}$. $\mathrm{H}$. attained a maximum of 61 per cent above the control level and remained high until the excess of urea had been eliminated, a matter of some three or four days after its administration had been stopped. As will appear later, there is a rather striking parallelism between increase in proteinuria after urea and after the ingestion of a large supplementary feeding of protein. 
TABLE V

Protein metabolism before and after intravenous plasma protein in Case $R . P$.

\begin{tabular}{|c|c|c|c|c|c|c|c|c|c|c|c|c|c|c|}
\hline \multirow[b]{2}{*}{ Period } & \multirow{2}{*}{$\begin{array}{c}\text { Day } \\
\text { of } \\
\text { period }\end{array}$} & \multirow[b]{2}{*}{ Diet and remarks } & \multirow{2}{*}{$\begin{array}{c}\text { Pro- } \\
\text { tein } \\
\text { intake }\end{array}$} & \multirow{2}{*}{$\begin{array}{c}\text { Urine } \\
\text { non- } \\
\text { protein } \\
\text { nitro- } \\
\text { gen }\end{array}$} & \multirow{2}{*}{$\begin{array}{c}\text { Stool } \\
\text { nitro- } \\
\text { gen }\end{array}$} & \multirow{2}{*}{$\begin{array}{l}\text { Urine } \\
\text { pro- } \\
\text { tein }\end{array}$} & \multirow[b]{2}{*}{ Balance } & \multicolumn{3}{|c|}{ Blood } & \multirow{2}{*}{$\begin{array}{l}\text { Plasma } \\
\text { vol- } \\
\text { ume }\end{array}$} & \multirow{2}{*}{$\begin{array}{l}\text { Urine } \\
\text { vol- } \\
\text { ume }\end{array}$} & \multirow{2}{*}{$\begin{array}{l}\text { Stand- } \\
\text { ard } \\
\text { urea } \\
\text { clear- } \\
\text { ance }\end{array}$} & \multirow{2}{*}{$\begin{array}{l}\text { Body } \\
\text { weight }\end{array}$} \\
\hline & & & & & & & & $\begin{array}{c}\text { Non- } \\
\text { protein } \\
\text { nitro- } \\
\text { gen }\end{array}$ & $\begin{array}{l}\text { Serum } \\
\text { albumin }\end{array}$ & $\begin{array}{l}\text { Serum } \\
\text { globulin }\end{array}$ & & & & \\
\hline $\begin{array}{c}\text { s } \\
\text { daye } \\
\text { each }\end{array}$ & & & $\begin{array}{l}\text { grams of } \\
\text { nitrogen } \\
\text { per diem }\end{array}$ & $\begin{array}{l}\text { grams } \\
\text { per } \\
\text { diem }\end{array}$ & $\begin{array}{c}\text { grams } \\
\text { per } \\
\text { diem }\end{array}$ & $\begin{array}{l}\text { grams of } \\
\text { nitrogen } \\
\text { per diem }\end{array}$ & $\begin{array}{l}\text { orams of } \\
\text { nitropen } \\
\text { per diem }\end{array}$ & $\begin{array}{c}\text { mom. } \\
\text { per } \\
\text { cent }\end{array}$ & per cent & per cent & $\mathbf{m l}$. & $\begin{array}{l}\text { ml.per } \\
\text { diem- } \\
\text { Average }\end{array}$ & $\underset{\substack{\text { ml. } \\
\text { minute }}}{\text { mer }}$ & kgm. \\
\hline $1-3$ & Average & Contr & 10.67 & 7.88 & 1.34 & 1.47 & +0.18 & 35 & $\begin{array}{l}2.46 \\
2.51\end{array}$ & $\begin{array}{l}1.83 \\
1.67\end{array}$ & & 1415 & 28 & 61.84 \\
\hline $4-7$ & Average & 2500 calories & 10.67 & 6.92 & 1.34 & 1.40 & +1.04 & 35 & 2.35 & 1.63 & 3060 & 1632 & 28 & 61.07 \\
\hline $8-11$ & 1 & & $\begin{array}{l}10.67 \\
10.67\end{array}$ & $\begin{array}{l}6.72 \\
6.67\end{array}$ & $\begin{array}{l}1.34 \\
1.34\end{array}$ & $\begin{array}{l}1.47 \\
1.42\end{array}$ & $\begin{array}{l}+1.14 \\
+1.24\end{array}$ & 35 & $2.56^{*}$ & 1.57 & 2820 & $\begin{array}{l}1640 \\
1658\end{array}$ & 25 & $\begin{array}{l}61.64 \\
61.53\end{array}$ \\
\hline 12 & 2 & $\begin{array}{l}\text { Control diet plus } \\
\text { Plasma protein } 41 \text { grams } \\
\text { Plasma nonprotein nitro- } \\
\text { gen } 0.16 \text { grams }\end{array}$ & $\begin{array}{r}10.67 \\
6.72\end{array}$ & & & & & 36 & $\begin{array}{l}2.94 * * \\
3.03 \dagger\end{array}$ & $\begin{array}{l}1.51 \\
1.65\end{array}$ & & & & \\
\hline & & Intravenously & 17.39 & 7.28 & 1.34 & 2.09 & +7.78 & 33 & $3.08 \ddagger$ & 1.55 & 3850 & 2270 & 38 & 61.31 \\
\hline $\begin{array}{l}13 \\
14 \\
15 \\
16\end{array}$ & $\begin{array}{c}\mathbf{3} \\
\mathbf{1} \\
\mathbf{2} \\
\mathbf{3} \\
\text { Average } \\
\text { Average } \\
\text { Average }\end{array}$ & Control diet & $\begin{array}{l}10.67 \\
10.67 \\
10.67 \\
10.67 \\
10.67 \\
10.67 \\
10.67\end{array}$ & $\begin{array}{l}6.85 \\
6.31 \\
6.07 \\
6.24 \\
6.71 \\
6.49 \\
6.82\end{array}$ & $\begin{array}{l}1.34 \\
1.34 \\
1.34 \\
1.34 \\
1.34 \\
1.34 \\
1.34\end{array}$ & $\begin{array}{l}2.52 \\
2.46 \\
2.17 \\
2.04 \\
1.89 \\
1.74 \\
1.70\end{array}$ & $\begin{array}{r}+0.34 \\
+0.56 \\
+1.09 \\
+1.05 \\
+0.73 \\
+1.10 \\
+0.80\end{array}$ & $\begin{array}{l}32 \\
35\end{array}$ & $\begin{array}{l}2.77 \\
2.52\end{array}$ & $\begin{array}{l}1.69 \\
1.68\end{array}$ & 3050 & $\begin{array}{l}1720 \\
1575 \\
1515 \\
1560 \\
1693 \\
1600 \\
1650\end{array}$ & $\begin{array}{l}27.5 \\
27 \\
27\end{array}$ & $\begin{array}{l}61.38 \\
61.42 \\
61.48 \\
61.68 \\
61.76 \\
62.05 \\
62.29\end{array}$ \\
\hline
\end{tabular}

* Before transfusion.

** 10 minutes after transfusion.

+6 hours after transfusion.

$\ddagger 21$ hours after transfusion.

The effect of increasing the volume of the plasma and the level of plasma protein by transfusion

The immediate effect of transfusion of plasma protein was found to be an increase in the concentration of protein in the plasma and an increase in plasma volume. The data from such an experiment are recorded in Table V. During a preliminary period of thirty-four days Case R. P. was kept on a constant diet, the protein and caloric content of which was fixed at a level found to be sufficient to permit the daily deposition of a small amount of protein. The patient's activity was limited to walking about his room. When catabolism, proteinuria and protein deposition were all fairly constant (Period 12 ) he received a transfusion of 783.5 grams of citrated plasma from compatible donors. The actual volume of the transfusion was $771 \mathrm{ml}$. On analysis the transfusion mixture was found to contain 6.56 grams of protein nitrogen and 0.16 gram of nonprotein nitrogen. Ninety-five ml. of physiological sodium chloride solution were used to wash the plasma from the gravity apparatus into the vein.

Previous to transfusion the concentration of serum proteins was nearly constant at 4.0 to 4.1 grams per cent. The maximum rise after transfusion was noted at the end of 6 hours, when a concentration of 4.68 grams per cent was recorded. Measurement of the plasma volume 21 hours afterward showed an increase about equivalent to the quantity of fluid injected.

Proteinuria increased and remained at levels higher than control for fourteen days. At the end of this time, the concentration of serum protein had fallen to the pretransfusion level, and the sum of the daily increments in proteinuria had now slightly exceeded the total amount of transfused protein. The urea clearance rose during the period of increased plasma volume and, it seems logical to infer increased glomerular filtration until the second day after transfusion, when it was found that urea clearance and plasma volume were essentially as in control periods. Increases in proteinuria thereafter were presumably associated with the slight increase in the concentration of plasma protein.

\section{Lag in proteinuria}

It has been observed that a change from a lower to a higher level of protein in the diet is some- 
TABLE VI

Protein metabolism and proteinuria as affected by large supplementary feedings of protein given during a single day

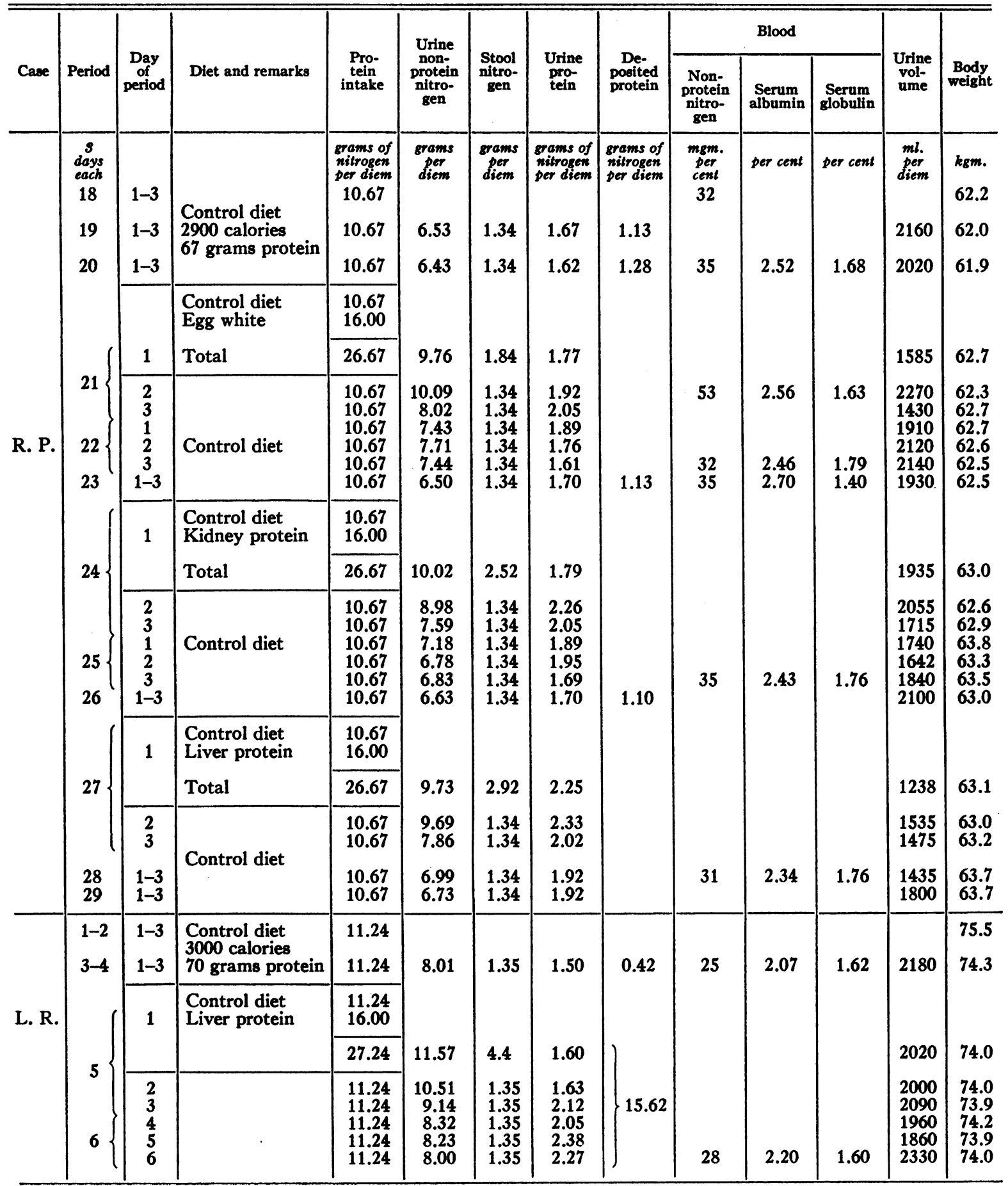


times followed by a prompt increase in proteinuria; at other times there is a delay before the increase in urinary protein appears. Whipple and collaborators have noted a similar delay in formation of plasma proteins in the dog, and attributed it to filling of reserve depots previously depleted of protein (29). Falta found considerable lag in excretion of nitrogen following superposition of certain proteins on a control diet (9). Lag was attributed to deposition of protein in the tissues and subsequent catabolism of it.

Table VI shows the effect of adding a large quantity of protein to a standard diet during a single day. Supplementary feedings of egg white, kidney and liver protein were given. In each case the amount of protein fed contained 16 grams of nitrogen. Catabolism of protein, as represented by the nonprotein nitrogen of the urine, was greatest on the day of ingestion of extra protein or on the following day and gradually declined to the control level three or four days later. Any diuretic effect ${ }^{1}$ of the protein supplement should have been operative during this interval. As the table indicates, proteinuria was usually at a maximum a day or two following the day on which the maximum excretion of nonprotein nitrogen occurred. After ingestion of liver protein both patients continued to excrete a considerable amount of excess protein in the urine, even when the urinary nonprotein nitrogen had returned to basal values. No evidence of increase in the concentration of serum protein was found, an observation in agreement with previous determinations of plasma proteins during such periods of increased proteinuria (18). The delay in attainment of maximum proteinuria was similar to that observed when urea was administered. In the absence of sufficiently complete data an hypothesis may be tentatively offered to explain the delayed rise in urinary protein on feeding liver protein and the persistence of this rise after evidence of increased catabolism of protein had disappeared. On feeding urea, it was noted that the full effect on glomerular filtration in terms of proteinuria was not achieved until the second or third day of the experiment. This is probably because time is required for the expansion of plasma volume pre-

\footnotetext{
1 The term "diuretic effect" as used above is synonymous with increased glomerular filtration.
}

ceding increased renal blood flow. Furthermore, it has been clearly shown that in dogs undergoing plasmapheresis an increase of protein in the ration increases the formation of plasma protein and that this effect persists for a varying interval of time after the protein supplement has been discontinued (29). In the present instance both of the aforementioned factors may have been operative. The long delay in reverting to basal conditions is probably due to increased production of plasma protein. When the tissues receive the components of plasma protein, an interval of two or three days may elapse before the synthesis of new protein is completed. Thereafter, it may be picked up slowly by the circulating plasma and escape in the urine. This is equivalent to stating that protein is first deposited in a depot and subsequently given up to the blood.

\section{DISCUSSION}

Despite gaps in our knowledge, currently recognized factors give a fairly clear picture of the mechanism of proteinuria. The rôle played by increase in glomerular permeability with resultant fall in the level of plasma proteins, the latter effect in turn leading to a heightened stimulus for the formation of these proteins, has already been discussed (18). The response to the stimulus leading to production of plasma proteins is partly dependent upon dietary sources and partly upon available stores of protein in the tissues. The amount of protein which can ultimately be contributed to the plasma by the tissues is evidently very large, but the readiness with which the tissues give up protein depends upon the presence of a labile reserve of protein in them. This seems to be but a relatively small fraction of the total protein of an organ or tissue. It may be rapidly depleted when plasma protein is needed and conversely quickly restored under optimal nutritional conditions. This fraction has been thought of in the past as a separate entity or depot, but the work of Luck (22) probably establishes its existence as an integral part of the cellular structure of the body, indistinguishable from other tissue proteins. The existence in the liver of such labile protein has been demonstrated by Addis, Poo and Lew (2). Replacement of this labile protein or the fact that plasma proteins must pass through the labile protein stage may be responsible for the lag 
in their appearance in the urine under favorable nutritional conditions. Data in Table VI suggest that protein may at times be temporarily retained in the labile fraction during the process of being converted into circulating plasma protein.

The balance of the protein of the body seems to be more firmly bound. Even large additions to tissue and organ proteins do not seem to influence the concentration of plasma proteins nor proteinuria (18). Yet a small addition to labile stores is reflected in an increased proteinuria, presumably through the medium of increase in the rate of formation of plasma proteins. When the store is exhausted, proteinuria returns to its previous level.

The rate of glomerular filtration has a definite influence on the magnitude of proteinuria. Variations in the rate of filtration may be brought about by changes in protein intake or by other changes in protein metabolism which Pitts (27) has found to be intimately associated with changes in renal activity. In the experiments in this paper, variations in the rate of glomerular filtration were produced by diuretic substances, by increasing the volume of blood and by changing the protein content of the diet. It is only by the use of diuretics that one may clearly separate the effect of changes in the rate of glomerular filtration from other factors which tend to change proteinuria. We have used the urea clearance as evidence of change in rate of filtration. While this clearance does not give an absolute measure of the amount of glomerular filtrate formed, it is safe to state that changes in urea clearance in any one individual are accompanied by changes in glomerular filtration in the same direction (32). Van Slyke, Rhoads, Hiller and Alving (33) found that changes in urea clearance were accompanied by parallel changes in renal blood flow. Bing (6) and Berglund and coworkers (4) have measured proteinuria in combination with creatinine clearance. The results were similar to ours.

Employment of a method giving a true measure of the amount of glomerular filtrate formed and simultaneous measurements of proteinuria would be necessary to establish the exact relationship between the two. Even then it is doubtful if one could expect more than qualitative changes in the same direction. Proteinuria varying in a manner exactly proportional to the amount of filtrate would require that increase in permeability take place by uniform enlargement of the pores in the filtering membrane. As Richards et al. (30) have pointed out, it is likely that damage results in the formation of abnormal pores of varying size scattered throughout the glomeruli. These permit the escape of minute amounts of serum as well as occasional erythrocytes. Such irregularity of damage could explain the minor variations in proteinuria we have found from day to day in patients on a uniform regime, as well as the lack of uniformity in daily albumin: globulin ratios of the urinary proteins.

The preceding discussion does not include the possibility, suggested by Ekehorn (34), of serum protein being reabsorbed by the tubular epithelium. He advanced this possibility because smaller amounts of protein were found in the bladder urine of certain animals than could be explained from its concentration in the glomerular filtrate when the latter was obtained by direct puncture of the glomerular capsule. He assumed that the protein concentration of the particular glomerulus was representative of that in all the glomeruli of the kidney, a doubtful assumption under the conditions. Reabsorption of hemoglobin in the tubules has also been suggested by several investigators $(34,35)$. The basis for this suggestion was the finding of iron staining pigment in the tubule cells of patients with hemoglobinuria or animals which had been given hemoglobin intravenously. The splitting of the hemoglobin in the lumina of the tubules and subsequent absorption of the pigment derivative is equally likely, especially since some of the iron staining pigment has usually been found in the tubular lumina as well as in the epithelial cells.

\section{SUM MARY}

Simultaneous increases in proteinuria and urea clearance have been produced by increasing the protein of the diet, by administration of diuretics and by increasing the volume of the blood plasma. The latter effect was accomplished by transfusion of plasma. A somewhat higher concentration of plasma protein persisted for some time after readjustment of the plasma volume to the pretrans- 
fusion level and was accompanied by loss of more protein in the urine.

Increases in proteinuria in Bright's disease may be explained by the presence of one or more of the following factors:

(a) Increase in glomerular permeability.

(b) Increase in the rate of glomerular filtration.

(c) Presence in diet or in body reserves of more new material from which plasma proteins may be constructed.

(d) Artificial increase in the concentration of plasma protein such as follows transfusion.

\section{BIBLIOGRAPHY}

1. Addis, T., and Drury, D. R., The rate of urea excretion. VII. The effect of various other factors than blood urea concentration on the rate of urea excretion. J. Biol. Chem., 1923, 55, 629.

2. Addis, T., Poo, L. J., and Lew, W., Protein loss from liver during a two day fast. J. Biol. Chem., 1936, $115,117$.

The rate of protein formation in the organs and tissues of the body. I. After casein refeeding. J. Biol. Chem., 1936, 116, 343.

3. Addis, T., and Watanabe, C. K., A method for the measurement of the urea excreting function of the kidneys. J. Biol. Chem., 1916-17, 28, 251.

4. Berglund, H., Scriver, W. de M., and Medes, G., Proteinuria and Plasma Proteins. The Kidney in Health and Disease. By Berglund, Medes, Huber, Longcope and Richards. Chapter 30. Lea and Febiger, Philadelphia, 1935.

5. Berglund, H., and Sundh, B., The effect of salyrgan, theophylline, and caffeine on diuresis, glomerular filtration, and proteinuria. Acta. med. Scandinav., 1935, 86, 216.

6. Bing, J., Studies on proteinuria "albuminuria." Acta med. Scandinav., 1936, Supp. 76.

7. Bulger, H. A., Studies of hypoproteinemia and proteinuria. J. Clin. Invest. (Proc.), 1935, 14, 705.

8. Cushny, A. R., The Secretion of the Urine. Longmans, Green, and Co., London, 1926, 2d ed.

9. Falta, W., Studien über den Eiweissstoff wechsel. II. tber den zeitlichen Ablauf der Eiweisszersetzung im tierischen Organismus. Deutsches Arch. f. klin. Med., 1906, 86, 517.

10. Fletcher, W. M., Henderson, V. E., and Loewi, O., Untersuchungen zur Physiologie und Pharmakologie der Nierenfunction. III. Ueber den Mechanismus der Caffeindiurese. Arch. f. exper. Path. u. Pharmakol., 1905, 53, 15.

11. Frandsen, J., Eiweissausscheidung bei chronischen Nephritikern. Acta med. Scandinav., 1926-27, 65, 341.
12. Gottlieb, R., and Magnus, R., Ueber Diurese. IV. Ueber die Beziehungen der Nierencirculation zur diurese. Arch. f. exper. Path. u. Pharmakol., 1901, 45, 223.

13. Henderson, V. E., and Loewi, O., Untersuchungen zur Physiologie und Pharmakologie der Nierenfunction. V. Uber den Mechanismus der Harnstoffdiurese. Arch. f. exper. Path. u. Pharmakol., 1905, 53, 49.

14. Hiller, A., McIntosh, J. F., and Van Slyke, D. D., The excretion of albumin and globulin in nephritis. J. Clin. Invest., 1927, 4, 235.

15. Hooper, C. W., Smith, H. P., Belt, A. E., and Whipple, G. H., Blood volume studies. I. Experimental control of a dye blood volume method. Am. J. Physiol., 1920, 51, 205.

16. Kingsbury, F. B., Clark, C. P., Williams, G., and Post, A. L., The rapid determination of albumin in urine. J. Lab. and Clin. Med., 1926, 11, 981.

17. Keith, N. M., Rowntree, L. G., and Geraghty, J. T., A method for the determination of plasma and blood volume. Arch. Int. Med., 1915, 16, 547.

18. Keutmann, E. H., and Bassett, S. H., Dietary protein in hemorrhagic Bright's disease. II. The effect of diet on serum proteins, proteinuria and tissue proteins. J. Clin. Invest., 1935, 14, 871.

19. Keutmann, E. H., and McCann, W. S., Dietary protein in hemorrhagic Bright's disease. I. Effects upon the course of the disease with special reference to hematuria and renal function. J. Clin. Invest., 1932, 11, 973.

20. Lamy, H., and Mayer, A., Etudes sur la diurèse. III. Sur les conditions des variations du débit urinaire (sécrétion de l'eau par le rein). J. de physiol. et de path. gen., 1906, 8, 258.

V. Les théories de la sécrétion rénale. Une nouvelle hypothèse sur l'anatomo-physiologie du rein. J. de physiol. et de path. gen., 1906, 8, 660 .

21. Landis, E. M., Elsom, K. A., Bott, P. A., and Shiels, E., Observations on sodium chloride restriction and urea clearance in renal insufficiency. J. Clin. Invest., 1935, 14, 525.

22. Luck, J. M., Liver proteins. I. The question of protein storage. J. Biol. Chem., 1936, 115, 491.

23. MacKay, E. M., Studies on urea excretion. V. The diurnal variation of urea excretion in normal individuals and patients with Bright's disease. J. Clin. Invest., 1928, 6, 505.

24. Möller, E., McIntosh, J. F., and Van Slyke, D. D., Studies of urea excretion. II. Relationship between urine volume and the rate of urea excretion by normal adults. J. Clin. Invest., 1928, 6, 427.

25. Page, I. H., The action of certain diuretics on the function of the kidney as measured by the urea clearance test. J. Clin. Invest., 1933, 12, 737.

26. Peters, J. P., and Van Slyke, D. D., Quantitative Clinical Chemistry. Volume II. Methods. Williams and Wilkins Co., Baltimore, 1932. 
27. Pitts, R. F., The effect of protein and amino acid metabolism on the urea and xylose clearance. J. Nutrition, 1935, 9, 657.

28. Polland, W. S., The effect of some diuretics on the urea excreting capacity of the kidney. Am. J. Physiol., 1928, 85, 141.

29. Pommerenke, W. T., Slavin, H. B., Kariher, D. H., and Whipple, G. H., Blood plasma protein regeneration controlled by diet. I. Systematic standardization of food proteins for potency in protein regeneration. Fasting and iron feeding. J. Exper. Med., 1935, 61, 261.

30. Richards, A. N., Westfall, B. B., and Bott, P. A., Inulin and creatinine clearances in dogs, with notes on some late effects of uranium poisoning. J. Biol. Chem., 1936, 116, 749.

31. Schmitz, H. L., Studies on the action of diuretics. I. The effect of euphyllin and salyrgan upon glomeru- lar filtration and tubular reabsorption. J. Clin. Invest., 1932, 11, 1075.

32. Shannon, J. A., Jolliffe, N., and Smith, H. W., The excretion of urine in the dog. IV. The effect of maintenance diet, feeding, etc. upon the quantity of glomerular filtrate. Am. J. Physiol., 1932, 101, 625.

33. Van Slyke, D. D., Rhoads, C. P., Hiller, A., and Alving, A. S., Relationships between urea excretion, renal blood flow, renal oxygen consumption, and diuresis. The mechanism of urea excretion. Am. J. Physiol., 1934, 109, 336.

34. Ekehorn, G., On the principles of renal function. Acta med. Scandinav., 1931, Supp. 36.

35. Newman, W. V., and Whipple, G. H., IV. Hemoglobin injections and conservation of pigment by kidney, liver, and spleen. The influence of diet and bleeding. J. Exper. Med., 1932, 55, 637. 